\title{
INDUKSI KEKEBALAN SPESIFIK PADA IKAN MAS, Cyprinus carpio Linn. TERHADAP INFEKSI KOI HERPESVIRUS (KHV) MELALUI TEKNIK KOHABITASI TERKONTROL
}

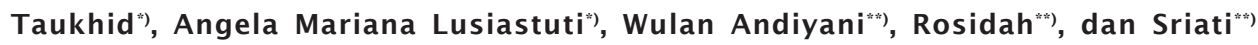 \\ *) Balai Riset Perikanan Budidaya Air Tawar \\ Jl. Raya Sempur No. 1, Bogor \\ E-mail: taukhid_as@yahoo.co.id; lusiastuti@yahoo.com \\ **) Fakultas Perikanan dan Ilmu Kelautan, Universitas Padjadjaran \\ Jl. Raya Bandung Sumedang Km 21, Jatinangor, Bandung 45363
}

(Naskah diterima: 26 Januari 2010; Disetujui publikasi: 12 Agustus 2010)

\begin{abstract}
ABSTRAK
Penelitian dengan tujuan untuk mengetahui masa induksi kekebalan spesifik hingga level protektif terhadap KHV pada populasi ikan mas yang diinfeksi secara buatan melalui teknik pemaparan terkontrol telah dilakukan pada skala laboratorium. Pemaparan terkontrol terhadap ikan positif KHV dilakukan selama 3 hari pada suhu $24^{\circ} \mathrm{C}-26^{\circ} \mathrm{C}$, selanjutnya ikan dipindahkan ke wadah volume 300 liter yang diisi ikan uji sebanyak 200 ekor/wadah dan suhu air berkisar antara $31^{\circ} \mathrm{C}-34^{\circ} \mathrm{C}$. Perlakuan yang diterapkan adalah periode induksi: (A) periode induksi selama 1 minggu dari akhir masa pemaparan terhadap KHV, (B) periode induksi selama 2 minggu dari akhir masa pemaparan terhadap $\mathrm{KHV}$, (C) periode induksi selama 3 minggu dari akhir masa pemaparan terhadap KHV, (D) periode induksi selama 4 minggu dari akhir masa pemaparan terhadap KHV, dan (E) tanpa periode induksi setelah dilakukan pemaparan terhadap KHV. Pada hari ke-21, seluruh kelompok perlakuan diinfeksi KHV secara buatan dengan teknik kohabitasi. Pengamatan dilakukan terhadap tingkah laku, gejala klinis, dan mortalitas ikan uji yang dilakukan setiap hari hingga akhir percobaan. Rataan persentase sintasan ikan uji tertinggi pada akhir riset diperoleh pada periode induksi selama 3 minggu sebesar $53,75 \%$; diikuti oleh periode induksi selama 2 minggu sebesar $33,75 \%$; selama 1 minggu sebesar 18,75\%; selama 4 minggu sebesar 12,5\%; dan kelompok kontrol sebesar 7,5\%.
\end{abstract}

KATA KUNCl: Koi Herpesvirus, induksi kekebalan, pemaparan terkontrol, ikan mas

ABSTRACT: Effective time period for specific immunity induction against Koi Herpesvirus on common carp (Cyprinus carpio Linn.) through cohabitation technique. By: Taukhid, Angela Mariana Lusiastuti, Wulan Andiyani, Rosidah, and Sriati

The research with the aim to study an effective period to develop specific immunity against Koi Herpesvirus on common carp population which was obtained by cohabitation technique had been done in laboratory scale. Cohabitation of KHV infected fish at $24^{\circ} \mathrm{C}-26^{\circ} \mathrm{C}$ was for 3 days, and then the fish was moved to fiber glass tank at $31^{\circ} \mathrm{C}-34^{\circ} \mathrm{C}$ to develop specific immunity. The treatments applied in the research were: (A) a week period induction, (B) two weeks period induction, (C) three weeks period induction, $(D)$ four weeks period induction, and $(E)$ without period induction as a control group. Fish test were challenge to KHV infection at the end of each defined period induction by cohabitation method for 2 weeks lasting. Examination on behavior, 
clinical signs, and mortality of fish test were taken place daily. The results showed that the highest survival rate was found on three weeks period induction (53.75\%), and followed by two weeks period induction (33.75\%), one week period induction (18.75\%), four weeks period induction (12.5\%), and the lowest was found on the control $(7.5 \%)$.

\section{KEYWORDS: Koi Herpesvirus, immunity, cohabitation, common carp}

\section{PENDAHULUAN}

Ikan mas (Cyprinus carpio Linn) merupakan salah satu komoditas ikan pangan strategis, pemasok protein hewani bagi jutaan rakyat Indonesia, baik di pedesaan maupun di perkotaan. Direktorat Jenderal Perikanan Budidaya (2002) melaporkan bahwa produksi perikanan air tawar didominasi oleh jenis ikan mas, yaitu sebesar 46,5\%; dan Provinsi Jawa Barat menyumbangkan sekitar $60 \%$ dari total produksi ikan mas nasional. Kasus kematian massal ikan mas akibat infeksi Koi Herpesvirus (KHV) di beberapa sentra budidaya sejak pertengahan tahun 2002, mengakibatkan produksi ikan mas nasional mengalami penurunan sekitar $40 \%$ selama kurun waktu 2002-2006. Secara kumulatif, kerugian ekonomi akibat penyakit tersebut hingga akhir 2006 diperkirakan mencapai lebih dari 250 milyar rupiah. Berbagai upaya pengendalian telah dilakukan, antara lain melalui pembentukan posko penanggulangan wabah, sosialisasi status penyakit, tindakan karantina, sarasehan/seminar/workshop, penyaluran bantuan, dan lain-lain termasuk pemberlakukan aturan khusus melalui Surat Keputusan Menteri Departemen Kelautan dan Perikanan No. 28/Men/2002, No. 40/Men/ 2002, serta Permen No. 55/Men/2004.

Koi Herpesvirus merupakan penyakit viral pada ikan mas dan koi (Cyprinus carpio) yang sangat menular, menginfeksi semua umur/ ukuran ikan dan sistem budidaya; mengakibatkan mortalitas antara 80\%-100\% dari total populasi ikan, dengan masa inkubasi antara 1-7 hari. Infeksi KHV dipicu oleh penurunan suhu lingkungan sehingga disebut sebagai virus yang menyerang saat dingin ( $a$ cold virus). Individu yang bertahan hidup (survivors) pada saat terjadi wabah umumnya akan menjadi tahan (resistant) terhadap infeksi berikutnya. Namun ketahanan tersebut tidak menunjukkan adanya transfer kepada keturunannya (maternal immunity). Secara klinis dan atau visual, infeksi KHV sering ditunjukkan dengan adanya nekrosa pada organ insang, ekses mukus, lepuh pada kulit, serta pergerakan renang yang tidak terarah (nervous movement) (Taukhid et al., 2005a).

Hingga kini belum tersedia teknologi pengendalian KHV yang memiliki tingkat keberhasilan dan kesesuaian yang tinggi untuk berbagai sistem budidaya ikan mas dan koi. Secara medis, infeksi virus sangat sulit dikendalikan dengan menggunakan obat/ bahan kimia dan strategi alternatif yang paling prospektif untuk pengendalian penyakit tersebut adalah melalui pendekatan ekologis dan biologis. Pendekatan ekologis antara lain dapat dilakukan dengan mengeksplorasi parameter lingkungan yang dapat memblokir kemampuan multiplikasi dan virulensi virus; sedangkan pendekatan biologis dapat dilakukan melalui pembekalan dini kekebalan tubuh, baik kekebalan spesifik maupun nonspesifik, serta pemanfaatan materi biologis lainnya yang berpotensi menghambat dan merusak kemampuan multiplikasi dan virulensi virus.

Riset ini bertujuan untuk mengetahui masa induksi kekebalan spesifik yang optimum hingga level protektif terhadap KHV pada populasi ikan mas yang diinfeksi secara buatan melalui teknik kohabitasi terkontrol.

\section{BAHAN DAN METODE}

\section{Ikan Uji}

Populasi ikan mas negatif KHV yang digunakan berasal dari satu batch yang diperoleh dari pembudidaya ikan di sekitar Bogor dengan rataan bobot badan $\pm 10 \mathrm{~g} /$ ekor. Kelompok ikan mas tersebut merupakan hasil pembenihan dari populasi induk ikan yang diketahui belum pernah terinfeksi KHV. Konfirmasi status penyakit tersebut, apakah negatif atau positif terinfeksi KHV, terlebih dahulu dilakukan diagnosa melalui deteksi gen KHV secara laboratoris dengan teknik Polymerase Chain Reaction (PCR) menurut metode yang dikembangkan oleh Gray et al. (2002). Selain patogen target, ikan uji juga diperiksa 
secara mikroskopis dan mikrobiologis terhadap adanya infeksi jenis patogen lainnya seperti parasit (protozoa, trematoda, crustacea), cendawan, dan bakteri.

Populasi ikan mas positif KHV sebagai sumber infeksi diperoleh dari pembudidaya/ pedagang ikan di sekitar Bogor dengan gejala klinis sedang terinfeksi KHV. Kepastian bahwa populasi ikan sumber infeksi tersebut positif terinfeksi KHV didasarkan pada batasan definisi kasus KHV yang dikembangkan oleh Taukhid et al. $\left(2005^{\mathrm{b}}\right)$, serta dikonfirmasi secara laboratoris melalui deteksi gen KHV dengan teknik PCR.

\section{Wadah dan Pemeliharaan Ikan Uji}

Wadah pemeliharaan ikan uji sebelum dan selama pelaksanaan riset didesinfeksi dengan menggunakan larutan kalium permanganat $\left(\mathrm{KMNO}_{4}\right)$ pada dosis $150 \mathrm{mg} / \mathrm{L}$ selama 24 jam, sedangkan serok, selang air, dan perlengkapan lain yang digunakan secara bersama selalu didesinfeksi dalam larutan kalium permanganat pada dosis $1.000 \mathrm{mg} / \mathrm{L}$.

Jumlah wadah yang digunakan selama periode perlakuan hingga sesaat sebelum proses uji tantang (pra uji tantang) adalah sebuah bak fiber glass volume 2.000 liter dan 6 (enam) buah bak fiber glass volume 300 liter, masing-masing bak ditutup dengan lembaran fiber glass. Empat buah bak yang digunakan sebagai wadah perlakuan ditempatkan dalam areal yang sama, masingmasing diisi ikan uji dengan kepadatan 100 ekor/bak. Sedangkan dua buah bak lainnya, digunakan untuk menampung ikan negatif dan positif KHV, masing-masing diisi ikan sebanyak 100 ekor dan ditempatkan pada areal yang terpisah (terisolasi).

Air pemeliharaan dilengkapi dengan pengudaraan (aerasi) yang diatur secara manual, sehingga diasumsikan masing-masing wadah memperoleh pasokan udara yang relatif sama. Pada masing-masing wadah pemeliharaan selama periode pra uji tantang dilengkapi dengan water heater (thermostat) (Rena, 150 watt) yang di-set pada kisaran suhu $30^{\circ} \mathrm{C}-32^{\circ} \mathrm{C}$ serta sebuah termometer maksimum-minimum (Briliant) yang di-reset setiap 24 jam. Penyiponan air pemeliharaan dilakukan 2 kali sehari (pagi dan sore) sebanyak 5\%-10\% dari total volume air.

Pakan yang diberikan selama kegiatan riset adalah pakan komersial (Taisho: FF-999) dengan kadar protein kasar sebesar 38\%. Pemberian pakan dilakukan 3 kali sehari pada pukul 08.00, 12.00, dan 16.00 sebanyak $3 \%$ dari total biomassa ikan sedangkan penyesuaian jumlah pakan dilakukan setiap 10 hari.

\section{Perlakuan}

Riset ini dilakukan dengan menggunakan metode eksperimen model Rancangan Acak Lengkap (RAL) dengan 6 (enam) perlakuan. Perlakuan yang diterapkan adalah periode induksi kekebalan spesifik ikan uji setelah dipapar (kohabitasi) secara terkontrol terhadap KHV selama $3 \times 24$ jam. Keenam kelompok tersebut adalah:

A. Periode induksi selama 1 minggu dari akhir masa pemaparan terhadap KHV

B. Periode induksi selama 2 minggu dari akhir masa pemaparan terhadap KHV

C. Periode induksi selama 3 minggu dari akhir masa pemaparan terhadap KHV

D. Periode induksi selama 4 minggu dari akhir masa pemaparan terhadap KHV

E. Tanpa periode induksi setelah dilakukan pemaparan terhadap KHV

Masing-masing perlakuan dilakukan pengulangan sebanyak 3 (tiga) kali. Untuk mengetahui ada tidaknya pengaruh perlakuan terhadap sintasan ikan uji, digunakan uji F. Apabila dari hasil uji tersebut menunjukkan adanya perbedaan yang nyata, maka dilanjutkan dengan uji jarak berganda Duncan.

\section{Uji Tantang}

Uji tantang dilakukan terhadap masingmasing kelompok perlakuan pada setiap akhir masa induksi yang diterapkan melalui teknik pemaparan (cohabitation) selama 14 hari. Uji tantang dilakukan dalam wadah pemeliharaan berupa bak plastik volume 80 liter yang diisi air sebanyak 60 liter, diisi ikan uji sebanyak 20 ekor dan ikan positif KHV sebagai sumber infeksi sebanyak 10 ekor per wadah. Untuk membedakan antara individu kelompok ikan uji dengan individu kelompok ikan sumber infeksi dilakukan melalui penanda (tagging) dengan memotong salah satu sirip dada ikan sumber infeksi. Ikan sumber infeksi yang mati selama proses uji tantang diganti dengan individu baru, sehingga proporsi ikan sumber infeksi selama berlangsungnya proses uji tantang adalah 1 ekor/6 liter air. 


\section{Pengamatan}

Pengamatan dilakukan terhadap tingkah laku, gejala klinis dan mortalitas ikan uji yang dilakukan setiap hari hingga akhir percobaan. Penghitungan differential leucocyte dan aktivitas fagositik dilakukan pada pra dan pasca uji tantang menurut metode yang dikembangkan oleh Anderson \& Siwicki (1995). Analisis beberapa parameter kualitas air yang meliputi $\mathrm{pH}$, oksigen terlarut, amonia, nitrit, dan bahan organik total dilakukan secara berkala setiap minggu; sedangkan suhu air (maksimumminimum) dilakukan setiap hari.

Deteksi gen KHV dengan teknik PCR dilakukan menurut metode yang dikembangkan oleh Gray et al. (2002) terhadap populasi ikan uji pada (1) sebelum proses aklimatisasi, (2) sesaat sebelum proses uji tantang, (3) serta pada hari ke-7 dan 14 saat uji tantang. Sedangkan pada populasi ikan sumber infeksi, deteksi gen KHV dilakukan (1) sebelum didatangkan ke lokasi riset, dan (2) sesaat sebelum proses uji tantang. Pengambilan sampel untuk masing-masing kelompok dilakukan dengan teknik sampling selektif (non-probability sampling) yang didasarkan pada tingkah laku dan gejala klinis, dengan ukuran sampel 4-10 ekor. Analisis sampel dengan teknik PCR dilakukan secara pooling terhadap sampel yang berasal dari kelompok perlakuan atau batch yang sama.

\section{HASIL DAN BAHASAN}

\section{Pengamatan Gejala Klinis Ikan Mas yang Terinfeksi KHV}

Pengamatan gejala klinis pada ikan uji dan ikan sumber KHV dilakukan sejak sebelum dilakukan penelitian ini. Sebelum dilakukan penelitian, ikan uji yang berasal dari petani ikan asal Ciampea harus dinyatakan sehat secara visual maupun dari hasil analisis PCR (Gambar 1).

Dari hasil pengamatan dapat dipastikan bahwa ikan yang sehat memiliki tandatanda pergerakan renang yang aktif, respon pakannya cepat, kondisi insang yang merah menyala, dan dari warna permukaan tubuh (sisik) tampak bercahaya (Gambar 2). Selain dilihat dari gejala klinis ikan yang akan dijadikan sebagai ikan uji juga tidak boleh memiliki sejarah hidup pernah terjadi kematian secara massal.

Sedangkan ikan yang akan dijadikan sebagai ikan sumber KHV harus terdapat gejala klinis terinfeksi KHV dan dinyatakan positif KHV dari hasil analisis PCR. Berdasarkan uji PCR, ikan yang berasal dari Instalasi Riset Plasma

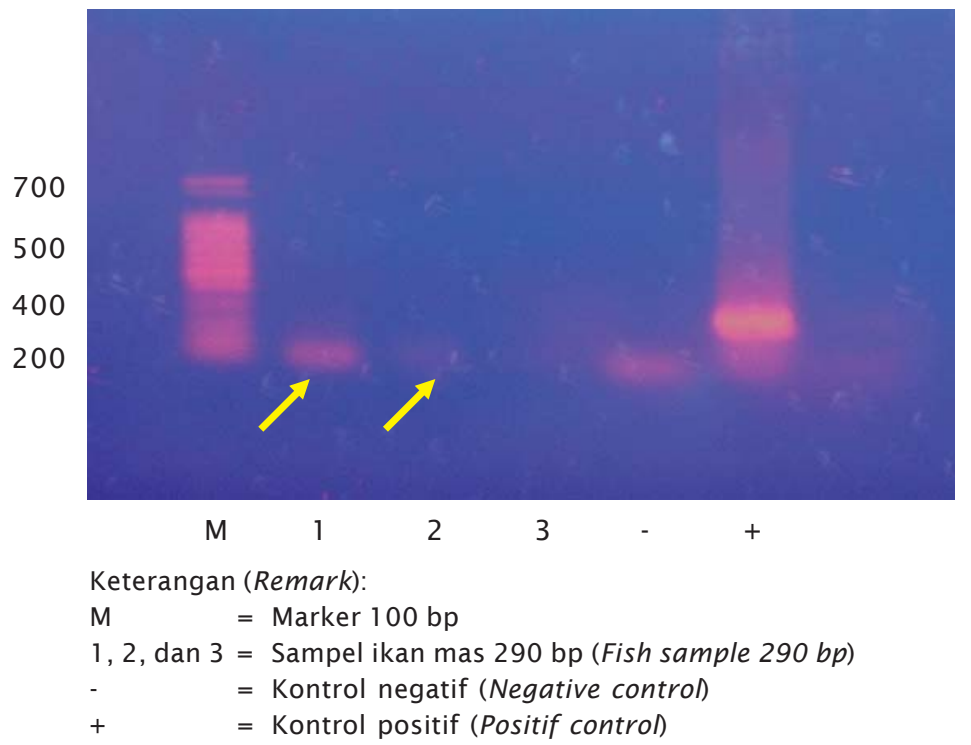

Gambar 1. Hasil diagnosa PCR ikan uji

Figure 1. The PCR result of fish samples 


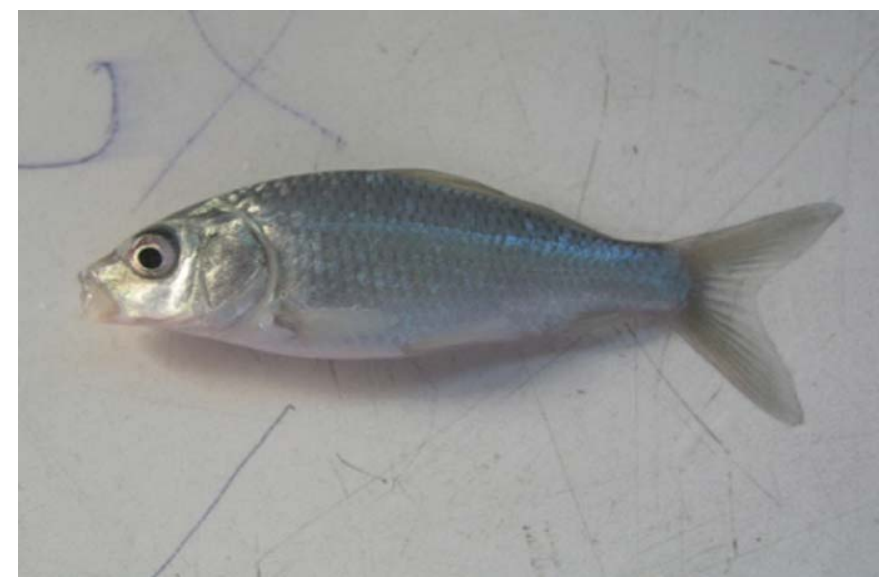

Gambar 2. Ikan uji sebelum perlakuan

Figure 2. Fish sample before treatment

Nutfah Perikanan Air Tawar (IRPNPAT) Cijeruk dan dari Pasar Anyar, dapat dipastikan positif KHV (Gambar 3).

Secara klinis ikan yang dijadikan sebagai sumber KHV sangat berbeda dari ikan uji, selain dari pergerakannya juga dari permukaan tubuh pun sangat berbeda. Ikan sumber KHV tampak pucat dan kondisi insangnya tidak secerah warna insang pada ikan uji (Gambar 4).
Pengamatan gejala klinis pada ikan mas yang telah terinfeksi KHV dilakukan pada masa kohabitasi selama tiga hari, pada waktu perlakuan yaitu pada saat virus diinkubasi pada badan ikan mas selama 1 minggu, 2 minggu, 3 minggu, dan 4 minggu serta pada masa uji tantang. Pada masa kohabitasi, ikan tidak menunjukkan gejala klinis secara visual. Namun setelah masa kohabitasi selama tiga

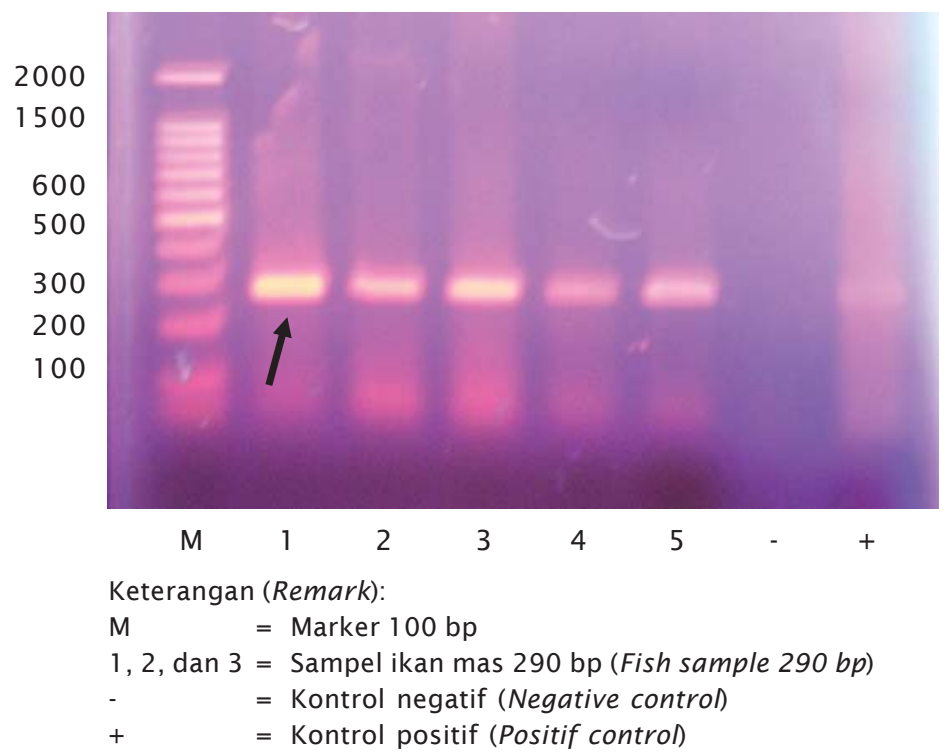

Gambar 3. Hasil diagnosa PCR ikan sumber KHV

Figure 3. The PCR result from $K H V$ fish 




Gambar 4. A (ikan sumber KHV), B (ikan uji)

Figure 4. $\quad$ A (KHV fish), B (sample of fish)

hari dapat dipastikan ikan sudah terinfeksi KHV. $\mathrm{Hal}$ itu dapat terlihat atas hasil uji PCR yang menunjukkan bahwa ikan, positif terkena KHV (Gambar 5).

Pada masa kohabitasi pergerakan ikan aktif, respon terhadap pakan bagus dan permukaan tubuh masih baik. Namun pada beberapa ikan setelah diamati tampak ada bercak putih pada insangnya. Setelah ikan dikohabitasi, kemudian ikan dimasukkan ke dalam bak yang dilengkapi pemanas air (heater) untuk menginkubasi virus pada badan ikan mas. Pada masa inkubasi, ikan tidak menunjukkan gejala klinis terinfeksi KHV karena ikan ditempatkan pada suhu antara $30^{\circ} \mathrm{C}-34^{\circ} \mathrm{C}$ sebagai suhu yang tidak cocok (non permisif) untuk KHV. Dari keempat perlakuan menunjukkan bahwa ikan nyaman di bak tersebut. Hal tersebut terlihat dari pergerakan ikan sangat aktif, respon pakan bagus, dan permukaan tubuh sangat baik. Jumlah pakan yang diberikan selalu habis dimakan ikan. Pada permukaan badan ikan tidak tampak ada luka atau infeksi sekunder. Dari hasil uji PCR, didapatkan hasil bahwa ikan uji negatif KHV (Gambar 5). Hal itu diduga, karena jumlah partikel virus menurun akibat kondisi lingkungan tidak permisif untuk melakukan replikasi, sehingga tidak dapat dideteksi atau tidak dapat tervisualisasi dengan uji PCR. Sedangkan pada perlakuan B, dari hasil uji PCR, dinyatakan ikan positif KHV namun kadarnya ringan.

Masa uji tantang, ikan menunjukkan gejala klinis terinfeksi KHV. Virus yang diinkubasi satu minggu (perlakuan A), hari pertama ikan dipindahkan ke akuarium, respon ikan terhadap pakan kurang. Ikan tidak mau makan pakan yang diberikan. Selain itu, pergerakan ikan tidak seimbang. Beberapa ikan berenang memisahkan diri dari ikan lain. Namun setelah beberapa jam ikan mulai berkumpul di dasar akuarium. Begitu pula dengan ikan pada perlakuan B, C, dan D. Hal itu terjadi karena ikan masih beradaptasi dengan lingkungan yang baru yaitu dari suhu $30^{\circ} \mathrm{C}-34^{\circ} \mathrm{C}$ ke suhu lingkungan yaitu $25^{\circ} \mathrm{C}-27^{\circ} \mathrm{C}$. Berbeda dengan ikan kontrol yang tidak mengalami perlakuan masa inkubasi virus, artinya ikan tidak mengalami masa pemeliharaan pada bak yang dilengkapi heater, ikan dapat langsung beradaptasi karena ikan tidak perlu menyesuaikan diri dengan suhu baru. Ikan hanya menyesuaikan dengan lingkungan wadah yang baru. Jadi setelah beberapa jam ikan sudah mau makan dan pergerakannya aktif.

Ikan pada perlakuan A menunjukkan gejala klinis pada hari ke-3. Hal itu terlihat dari ikan yang sudah mulai stres ditandai dengan ikan yang berenang tidak seimbang. Beberapa ikan berenang memisahkan diri dari kelompoknya. Sesuai dengan pernyataan Taukhid et al. (2004) bahwa faktor penyebab stres pada ikan dapat disebabkan oleh stressor kimiawi, yaitu nilai amonia dan nitrat yang tidak optimal, stressor biologi, yaitu kepadatan populasi dan hadirnya organisme yang bersifat patogenik (parasit, jamur, bakteri, dan virus). Respon ikan terhadap pakan masih baik dan kondisi badan 




Gambar 5. Hasil diagnosa ikan mas setelah dikohabitasi 3 hari

Figure 5. The results of fish diagnosis after 3 days cohabitation

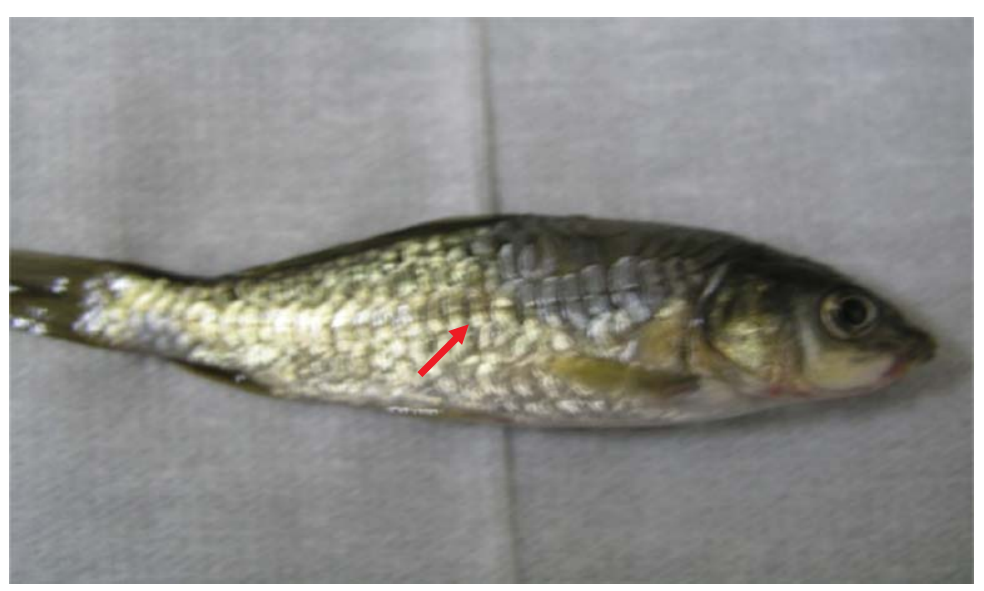

Gambar 6. Permukaan tubuh ikan yang kehilangan lendir

Figure 6. The surface of fish body that loses of mucus 


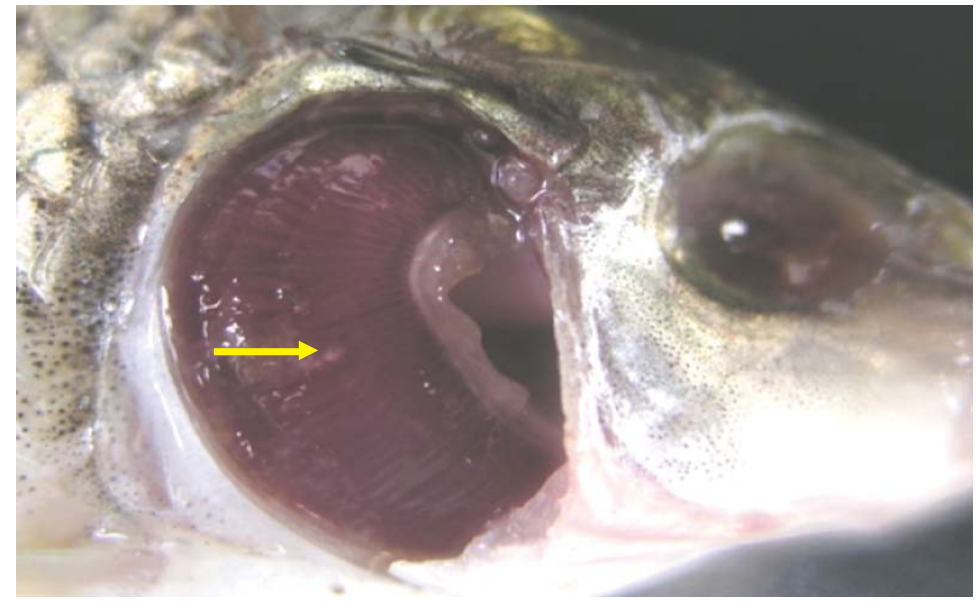

Gambar 7. Bintik kekuningan akibat infeksi Flexibacter columnaris

Figure 7. Yellow spots caused by Flexibacter columnaris infection

ikan masih sangat baik. Pada hari ke-4 ikan mulai kurang nafsu makan, ikan berenang di permukaan dan hilang keseimbangan. Selain itu permukaan badan ikan mulai ada gejala klinis. Sisik ikan mulai kering karena hilangnya lendir. Hal itu menandakan bahwa ikan mulai menunjukkan gejala klinis terkena KHV. Karena ikan yang terkena KHV akan menunjukkan gejala klinis produksi lendir (mucus) berlebih sebagai respon fisiologis terhadap kehadiran patogen, selanjutnya produksi lendir menurun drastis sehingga badan ikan terasa kasat (Taukhid et al., 2005 ${ }^{\mathrm{b}}$ ).
Pada hari ke-6 ikan pada perlakuan A, D, dan $E$ tampak berenang di permukaan disertai megap-megap. Selain itu, insang ikan tampak ada bintik-bintik kekuningan. Bintik-bintik kekuningan pada insang ikan mas ini diduga selain sebagai gejala KHV juga karena adanya infeksi bakteri Flexibacter columnaris (Gambar 7).

Hal itu sesuai dengan pernyataan Taukhid et al. $\left(2005^{\text {b }}\right)$ bahwa insang ikan yang positif KHV selalu ditemukan adanya infeksi Flexibacter columnaris. Pada hari ke-7 sudah

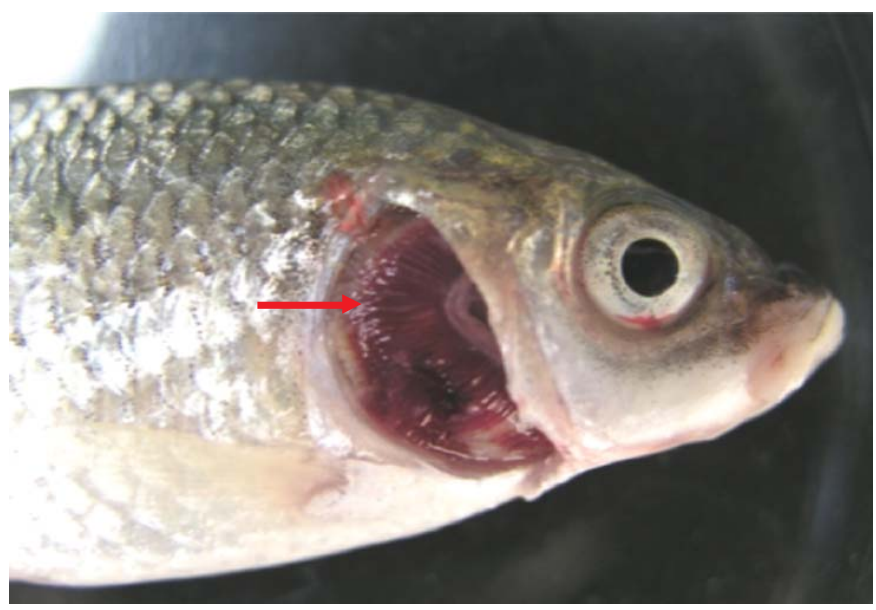

Gambar 8. Bintik putih pada insang

Figure $8 . \quad$ White spot on gills 


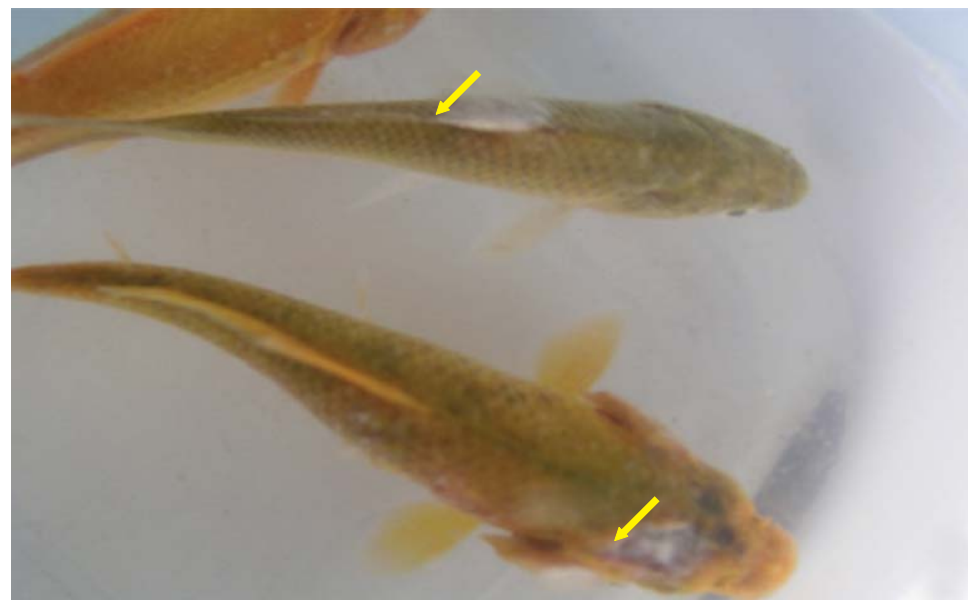

Gambar 9. Jamur pada permukaan tubuh ikan

Figure 9. Moulds in the surface of body fish

banyak ikan yang mengalami kematian dan tampak permukaan badan yang kasat dan insangnya pucat.

Pada hari ke-7 ini pada beberapa ikan uji dan ikan sumber infeksi terdapat jamur pada permukaan badannya (Gambar 9). Dari hasil identifikasi, jamur yang menginfeksi ikan tersebut adalah jamur Saprolegnia. Selain itu pada pangkal sirip terdapat luka. Pemeriksaan parasit juga dilakukan pada ikan uji dan ikan sumber infeksi dan ternyata terdapat parasit Dactylogyrus dan Myxobolus pada insang dan Trichodina pada lendir ikan.

Tidak berbeda dengan perlakuan $A$, perlakuan $B$ menunjukkan gejala klinis yang serupa dengan perlakuan $A$. Pada perlakuan B, C, dan D respons ikan terhadap pakan masih baik sampai hari ke-7. Walaupun pada hari ke-7 ikan sudah ada yang mengalami kematian, namun ikan-ikan yang mampu bertahan hidup masih mau makan pakan yang diberikan (Tabel 1).

Selain respon terhadap pakan, gejala klinis lain yang diamati adalah pergerakan (Tabel 2) dan kondisi badan ikan (Tabel 3). Pada Tabel 2 tampak bahwa pada awal ikan dipindahkan ke dalam akuarium, pergerakan ikan normal namun tidak aktif. Beberapa ikan berenang memisahkan diri dari kelompoknya. Setelah hari ke-1, ikan uji di semua perlakuan mulai bergerak aktif dan belum menunjukkan gejala terinfeksi KHV. Pada hari ke-5 ikan uji pada perlakuan $\mathrm{A}, \mathrm{D}$, dan $\mathrm{E}$ mulai menunjukkan pergerakan renang yang tidak normal seperti berenang yang kurang keseimbangan. Bahkan beberapa ikan berenang di permukaan dan tampak megap-megap. Pada hari ke-13 sampai 14 , ikan yang mampu bertahan hidup mulai berenang seimbang walaupun tidak bergerak aktif.

Pengamatan kondisi badan ikan pada masa uji tantang dapat dilihat pada Tabel 3. Pada awal ikan dipindahkan ke dalam akuarium untuk diuji tantang, ikan uji pada semua perlakuan masih dalam kondisi sangat baik. Secara visual tidak ada gejala ikan terinfeksi KHV. Penurunan kondisi tubuh tampak pada hari ke-5. Pada hari ke-5, gejala klinis yang tampak adalah sebagian dari permukaan tubuh yang kesat akibat dari produksi lendir yang menurun. Selain itu, pada insang terdapat bintik putih. Pada hari ke-7, sebagian besar permukaan badan ikan kehilangan lendir yang menyebabkan ikan kesat pada bagian sisiknya. Setelah hari ke-7, ikan pada semua perlakuan terdapat luka pada pangkal sirip. Selain itu, banyak ikan yang mengalami kerusakan seperti geripis pada insang dan sirip ekornya (Gambar 10).

\section{Pengamatan Kualitas Air pada Masa Pemeliharaan Ikan}

Kondisi perairan berperan dalam pengaturan homeostatis yang diperlukan bagi pertumbuhan dan reproduksi ikan. Perubahan faktor parameter air hingga batas-batas tertentu dapat menyebabkan stres dan timbul 


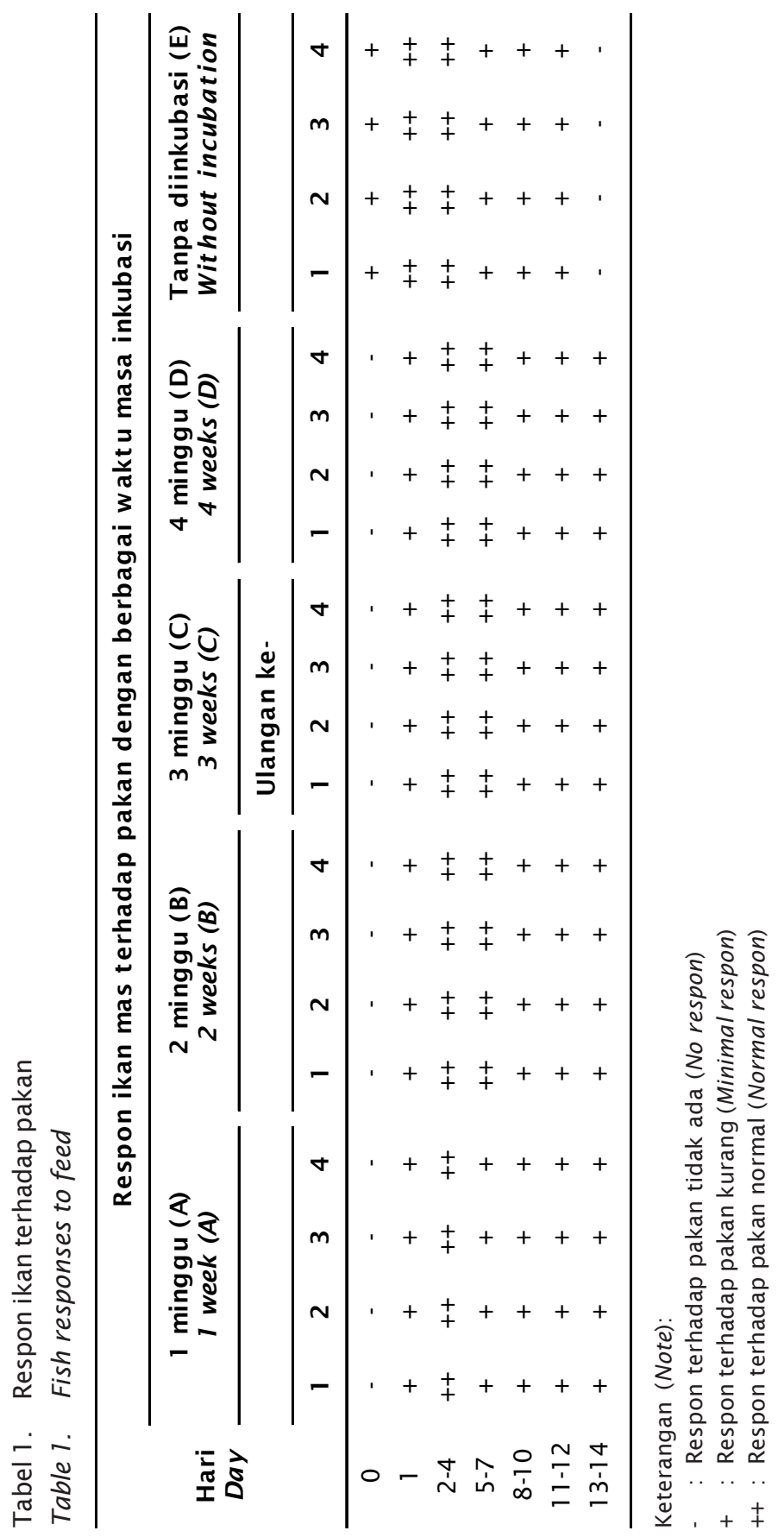




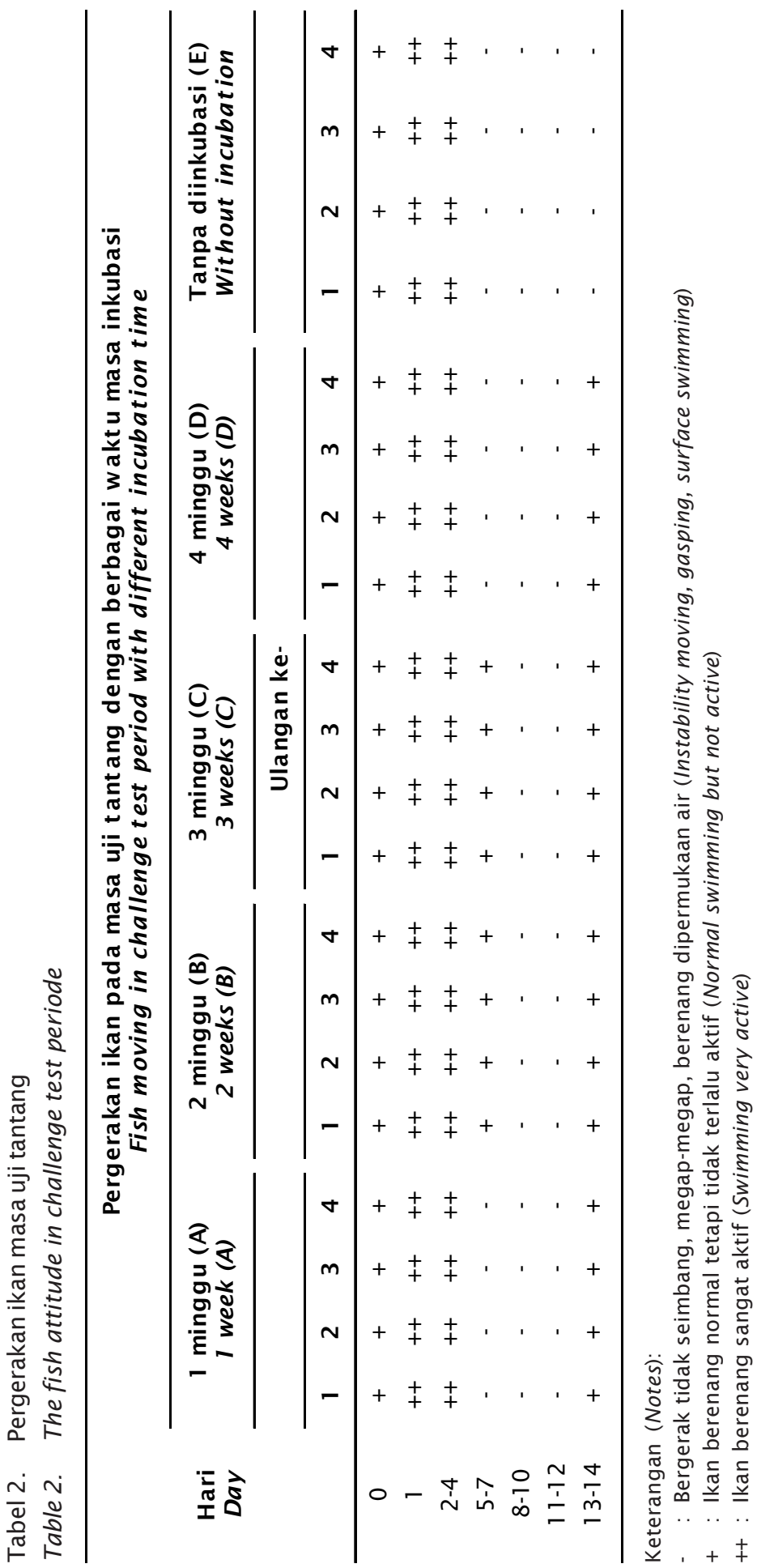




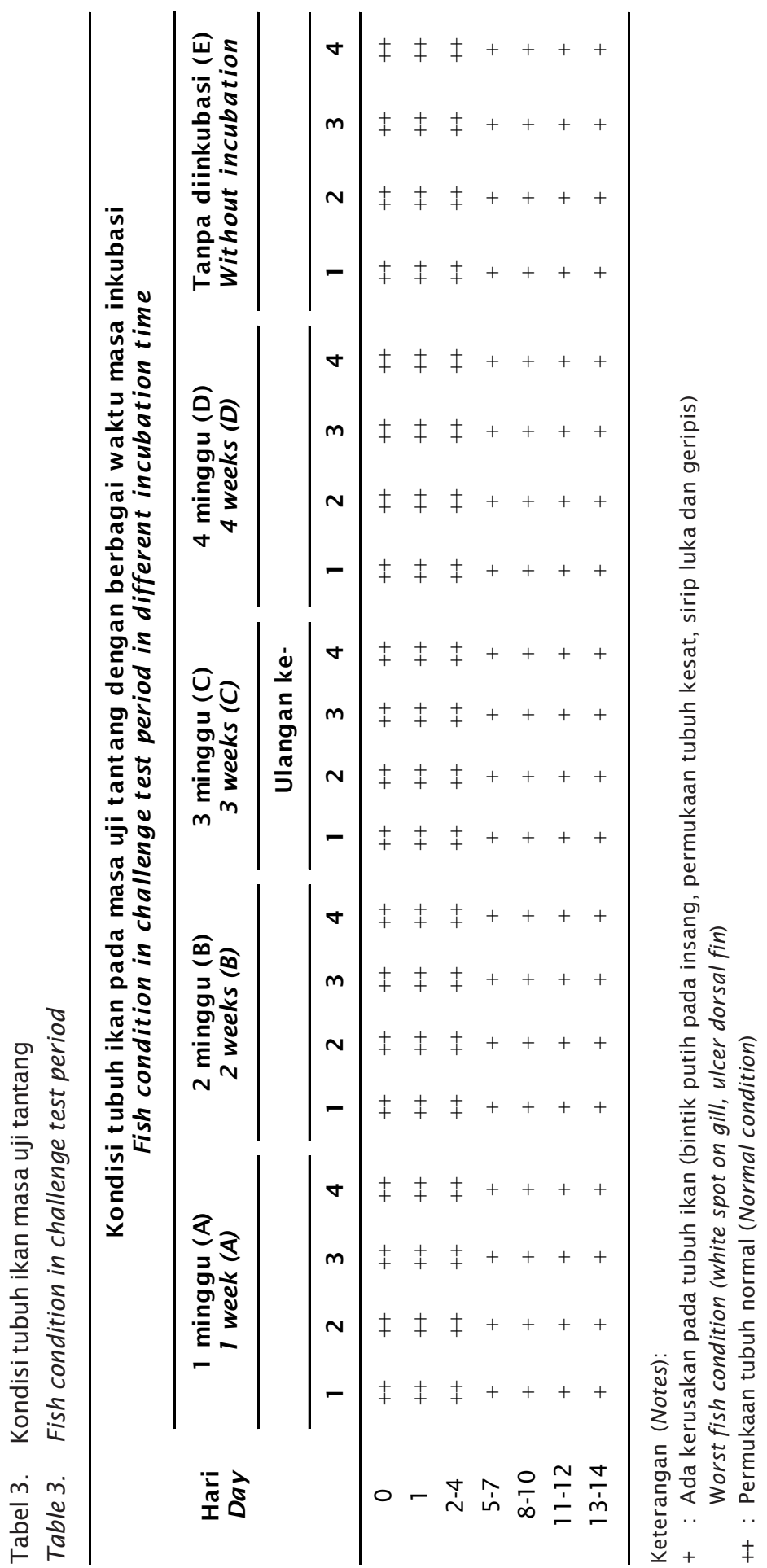




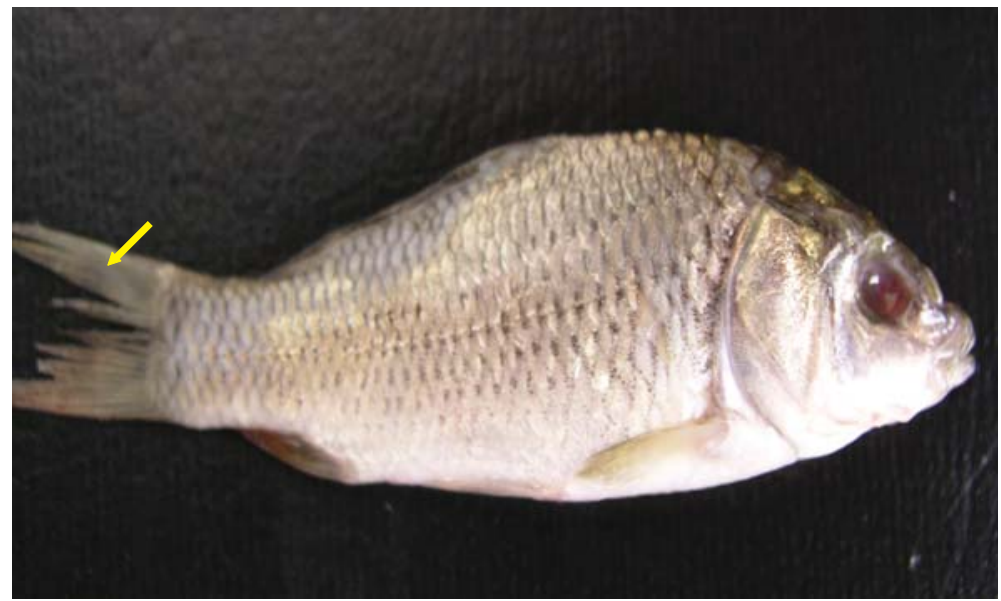

Gambar 10. Kondisi ikan pasca uji tantang 7 hari

Figure 10. Fish condition post challenge test 7 days

penyakit pada ikan. Parameter kualitas air yang penting untuk mendukung pertumbuhan badan ikan di antaranya suhu, $\mathrm{pH}$, amonia, nitrit, oksigen terlarut, dan bahan organik. Dari hasil penelitian ini didapatkan hasil analisis kualitas air seperti tertera pada Tabel 4.

Ikan memiliki derajat toleransi terhadap suhu dengan kisaran tertentu yang sangat berperan bagi pertumbuhan, konversi pakan, dan resistensi terhadap penyakit (Irianto, 2005). Ikan akan mengalami stres jika terpapar pada suhu di luar kisaran yang dapat ditoleransi. Kisaran toleransi suhu antara spesies ikan satu dengan ikan yang lainnya berbeda-beda. Kisaran suhu optimal untuk pertumbuhan badan ikan mas adalah $20^{\circ} \mathrm{C}$ $30^{\circ} \mathrm{C}$ (Khairuman, 2002). Namun pada penelitian ini, perlakuan yang digunakan adalah pemeliharaan ikan pada suhu terkontrol yaitu pada suhu $31^{\circ} \mathrm{C}-34^{\circ} \mathrm{C}$. Walaupun pada masa pemeliharaan ikan ditempatkan pada suhu di atas $30^{\circ} \mathrm{C}$, namun tidak ada kematian pada ikan sampai pemeliharaan hari ke-28. Seperti pernyataan Irianto (2005) bahwa suhu tinggi tidak selalu berakibat mematikan pada ikan, tetapi dapat menyebabkan gangguan status kesehatan untuk jangka panjang, misalnya stres yang ditandai dengan tubuh lemah, kurus, dan tingkah laku abnormal. Pada penelitian ini, ikan uji yang dipelihara pada suhu di atas $30^{\circ} \mathrm{C}$, tidak mengalami tingkah laku abnormal bahkan sebaliknya, ikan sangat aktif dan respons terhadap pakan sangat baik. Namun selama pemeliharaan, walaupun pakan yang dimakan ikan banyak namun bobot ikan tidak bertambah. Hal itu diduga karena metabolisme ikan pada suhu tinggi juga tinggi. Jadi walaupun ikan memakan banyak pakan tetapi kondisi ikan cenderung kurus. Sedangkan pada masa uji tantang, suhu air tidak dikontrol tetapi disesuaikan dengan lingkungan. Hal itu dimaksudkan untuk melihat kondisi lingkungan jika berada di alam yang selalu terjadi fluktuasi suhu yang tinggi.

Nilai $\mathrm{pH}$ air yang optimum untuk pertumbuhan ikan mas adalah 6-9 (Khairuman, 2002). Pada penelitian ini, pH air tidak mengalami perubahan yang tinggi. Dan sampai akhir penelitian, $\mathrm{pH}$ air masih dalam level normal. Besarnya nilai $\mathrm{pH}$ pada perairan dipengaruhi komposisi kimiawi air juga aktivitas biologis yang berlangsung di dalamnya.

Oksigen diperlukan ikan untuk katabolisme yang menghasilkan energi bagi aktivitas seperti berenang, reproduksi, dan pertumbuhan. Kebutuhan oksigen untuk ikan mas adalah $3 \mathrm{mg} / \mathrm{L}$. Pada masa pemeliharaan ikan dalam bak fiber, yaitu pada masa pemeliharaan ikan dalam suhu terkontrol, nilai oksigen terlarut pada semua perlakuan adalah antara 3,2-7,2. Nilai tersebut cenderung lebih rendah dari pada kandungan oksigen terlarut pada masa uji tantang. Hal itu dikarenakan pada masa pemeliharaan ikan dengan suhu terkontrol, padat tebar ikan lebih tinggi dari pada masa uji tantang. 
Tabel 4. Kisaran kualitas air selama penelitian

Table 4. Water quality on research period

\begin{tabular}{|c|c|c|c|c|c|c|}
\hline \multirow{2}{*}{$\begin{array}{l}\text { Perlakuan } \\
\text { Treatment }\end{array}$} & \multicolumn{6}{|c|}{$\begin{array}{c}\text { Parameter kualitas air } \\
\text { Parameter of water quality }\end{array}$} \\
\hline & $\begin{array}{c}\text { Suhu } \\
\text { Temperat ure } \\
\left({ }^{\circ} \mathrm{C}\right)\end{array}$ & pH & $\begin{array}{l}\mathrm{DO} \\
\mathrm{mg} / \mathrm{L}\end{array}$ & $\begin{array}{l}\text { Amonia } \\
\mathrm{mg} / \mathrm{L}\end{array}$ & $\begin{array}{l}\text { Nit rit } \\
\mathrm{mg} / \mathrm{L}\end{array}$ & BO \\
\hline Aklimatisasi & $25-27$ & 7 & 3.6 & 0.239 & 0.151 & \\
\hline Acclimatisation & & & & & & \\
\hline $\begin{array}{l}\text { Kohabitasi } \\
\text { Cohabitation }\end{array}$ & $24-26$ & 6.5 & 6.8 & 0.233 & 0.115 & 25.16 \\
\hline $\begin{array}{l}\text { A Suhu terkontrol (inkubasi virus) } \\
\text { Controlled temp. (virus incubation) }\end{array}$ & $31-34$ & 7 & 7.2 & 0.03 & 0.189 & 9.16 \\
\hline $\begin{array}{l}\text { Uji tantang } \\
\text { Challenge test }\end{array}$ & $24-27$ & 7 & 6.8 & 0.038 & 0.138 & 9.32 \\
\hline $\begin{array}{l}\text { B Suhu terkontrol (inkubasi virus) } \\
\text { Controlled temp. (virus incubation) }\end{array}$ & $31-34$ & 7 & 4.8 & 0.056 & 0.166 & 11.8 \\
\hline $\begin{array}{l}\text { Uji tantang } \\
\text { Challenge test }\end{array}$ & $24-26$ & 7 & 6.4 & 0.044 & 0.181 & 14.4 \\
\hline $\begin{array}{l}\text { C Suhu terkontrol (inkubasi virus) } \\
\text { Controlled temp. (virus incubation) }\end{array}$ & $31-34$ & 7 & 3.2 & 0.034 & 0.159 & 4.42 \\
\hline $\begin{array}{l}\text { Uji tantang } \\
\text { Challenge test }\end{array}$ & $24-26$ & 7.5 & 7.6 & 0.024 & 0.54 & 1.26 \\
\hline $\begin{array}{l}\text { D Suhu terkontrol (inkubasi virus) } \\
\text { Controlled temp. (virus incubation) }\end{array}$ & $31-34$ & 7 & 4.8 & 0.034 & 0.144 & 5.58 \\
\hline $\begin{array}{l}\text { Uji tantang } \\
\text { Challenge test }\end{array}$ & $24-27$ & 7.5 & 6.8 & 0.03 & 1,225 & 5.9 \\
\hline $\begin{array}{l}\text { E Uji tantang } \\
\text { Challenge test }\end{array}$ & $24-26$ & 7 & 6.4 & 0.053 & 0.151 & 16.46 \\
\hline
\end{tabular}

Amonia merupakan produk akhir utama katabolisme protein yang disekresikan ke luar badan ikan melalui insang dan kulit serta ikut berperan dalam regulasi ion melalui pertukaran dengan ion $\mathrm{Na}^{+}$(Willoughby, 1999 dalam Irianto, 2005). Kandungan amonia yang optimum untuk pertumbuhan ikan adalah di bawah 0,6 $\mathrm{mg} / \mathrm{L}$. Dari penelitian ini nilai amonia yang terkandung dalam air selama penelitian masih di bawah nilai optimum. Sumber lain menyatakan bahwa kandungan amonia untuk pertumbuhan ikan mas adalah di bawah 2,0 mg/L. Nilai amonia yang mencapai 2,0 $\mathrm{mg} / \mathrm{L}$ akan menyebabkan toksisitas akut pada ikan mas.

\section{Tingkat Sintasan}

Masa kohabitasi ikan yang dilakukan selama tiga hari tidak terjadi kematian pada ikan uji.
Kohabitasi selama tiga hari merupakan waktu yang efektif untuk menginfeksi ikan sehat sehingga menjadi ikan yang positif KHV. Walaupun pada masa kohabitasi tidak terjadi kematian pada ikan uji tetapi ikan-ikan sumber KHV terus mengalami kematian. Setiap jam dapat dipastikan ikan sumber KHV mengalami kematian mencapai 50\%-90\%. Hasil pengamatan terhadap tingkat sintasan ikan mas yang telah diinfeksi KHV, kemudian diberi perlakuan berupa perbedaan lama masa inkubasi virus pada badan ikan mas menunjukkan tingkat sintasan yang berbeda-beda. Tingkat sintasan terendah didapatkan pada ikan mas yang sehat kemudian langsung dikohabitasi dengan ikan mas yang telah terinfeksi KHV pada masa uji tantang (kontrol negatif). Ikan kontrol (perlakuan E), telah memberikan tingkat sintasan sebesar 7,5\% dan tertinggi diperoleh 


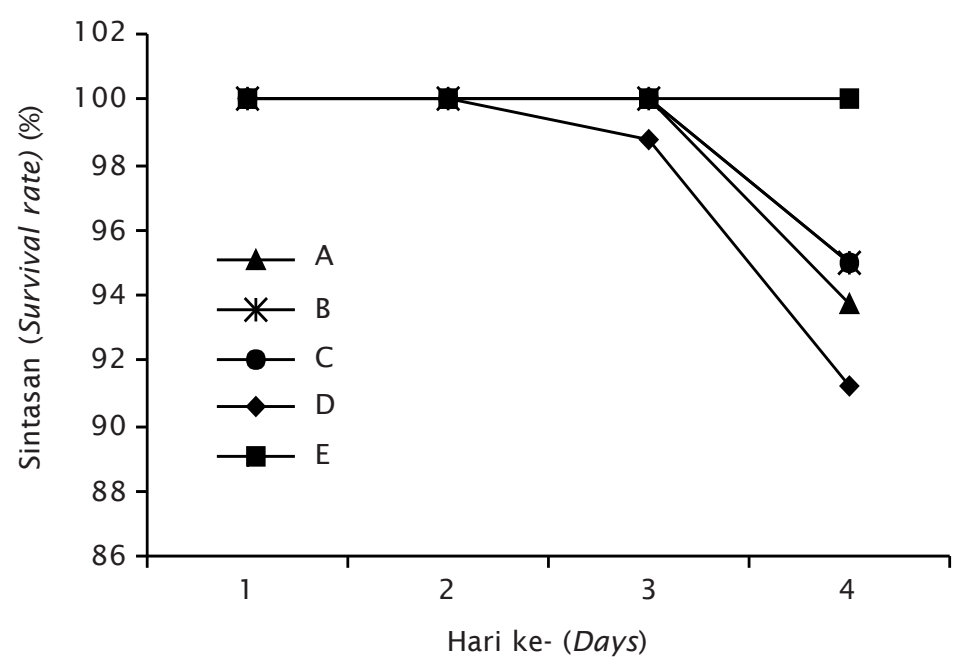

Gambar 11. Status kematian ikan hari pertama sampai hari ke-4

Figure 11. Fish mortality in the first day to fourth days

pada masa inkubasi virus selama tiga minggu (perlakuan C) yaitu sebesar 53,75\%.

Pada grafik (Gambar 11) terlihat bahwa pada awal pengamatan belum terjadi kematian pada ikan. Walaupun pada dasarnya patogen telah berada pada badan ikan yang sebelumnya telah infeksi KHV (perlakuan A, B, C, dan D), namun belum menjadi ganas karena kondisi lingkungan yang masih mendukung untuk pertahanan badan ikan terhadap penyakit. Pada hari ke-4 ikan uji setiap perlakuan telah mengalami kematian, kecuali pada ikan kontrol (E). Sedangkan ikan uji pada perlakuan E mulai terjadi kematian pada hari ke-5. Pada hari ke-5 ikan uji pada perlakuan E memberikan tingkat sintasan yang tinggi dibandingkan dengan perlakuan lain yaitu sebesar $98,75 \%$ (perlakuan E); 82,5\% (perlakuan A); $88,75 \%$ (perlakuan B); 87,5 (perlakuan C), dan 83,75 (perlakuan D).

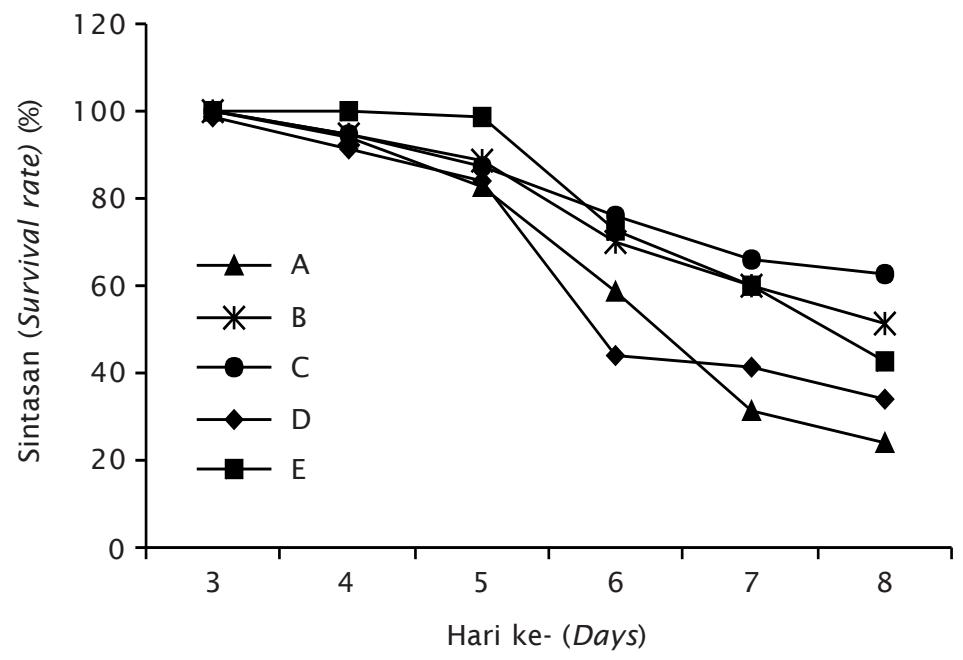

Gambar 12. Status kematian ikan hari ke-5 sampai hari ke-8

Figure 12. Fish mortality on fifth to eight days 
Hal itu disebabkan karena ikan uji pada perlakuan $A, B, C$, dan $D$ lebih cepat mengalami tingkat stres karena perubahan suhu dari suhu tinggi ke suhu rendah. Sesuai dengan pernyataan Taukhid et al. $\left(2005^{\text {b }}\right)$ bahwa virus herpes akan menjadi aktif jika ada faktor pemicu seperti perubahan lingkungan dan stres. Selain itu, virus akan ganas jika terjadi perubahan suhu dari tinggi ke rendah. Sesuai dengan pernyataan Hastowo \& Bibiana (1992) bahwa replikasi virus akan sangat cepat dibandingkan pembentukan antibodi jika terjadi perubahan suhu lingkungan dari tinggi ke rendah.

Pada hari ke- 6 dan ke- 7 setiap perlakuan telah memberikan tingkat kematian yang tinggi. Pada hari ke-6 sampai ke-8 inilah diduga sebagai puncak ganasnya virus KHV karena setelah hari ke- 8 dan selanjutnya tidak terjadi kematian yang tinggi, kecuali pada ikan kontrol (Gambar 12). Hal itu diduga karena ikan kontrol sama sekali tidak memiliki sistem kekebalan spesifik terhadap KHV. Ikan-ikan yang mampu mempertahankan hidup sampai hari ke-14 dapat dinyatakan bahwa ikan itu telah stabil dan resistence terhadap KHV. Hal itu dapat terlihat dari kondisi badan ikan yang kembali baik dan nafsu makan yang kembali meningkat.

Tingginya tingkat kematian pada hari ke- 6 dan ke-7 kemungkinan besar disebabkan proses replikasi dan virulensi virus pada badan ikan mas mulai tinggi sehingga daya tahan badan ikan alami ikan mas mulai melemah. Selain itu infeksi sekunder dapat dengan mudah masuk pada badan ikan mas karena saat ikan pada kondisi lemah dan pada kondisi lingkungan yang kurang menguntungkan (misalnya air tercemar, masa pergantian musim, perubahan suhu yang cepat), maka ikan menjadi rentan terhadap serangan patogen (Irianto, 2004). Infeksi sekunder yang dapat terlihat adalah adanya tumbuh jamur pada beberapa ikan uji dan ikan sumber. Selain jamur pada beberapa ikan uji tampak tumbuh parasit seperti Dactylogyrus dan Myxobolus. Hal itu sesuai dengan pernyataan Irianto (2005) bahwa pada suhu rendah, akibat yang ditimbulkan antara lain ikan menjadi lebih rentan terhadap infeksi fungi dan bakteri patogen akibat melemahnya sistem imun.

Rendahnya tingkat sintasan pada ikan yang tidak dikohabitasi/kontrol (perlakuan E), diduga karena pada badan ikan belum terbentuk sistem kekebalan spesifik KHV. Hal itu sesuai dengan pernyataan Irianto (2005) bahwa agar sistem pertahanan badan ikan berfungsi dengan baik maka ikan harus dipaparkan pada patogen atau produk-produk yang berasal dari patogen (misalnya LPS dan vaksin). Sedangkan rendahnya tingkat sintasan pada ikan uji dengan perlakuan masa inkubasi virus satu minggu (perlakuan A) dan masa inkubasi dua minggu (perlakuan B) diduga karena belum

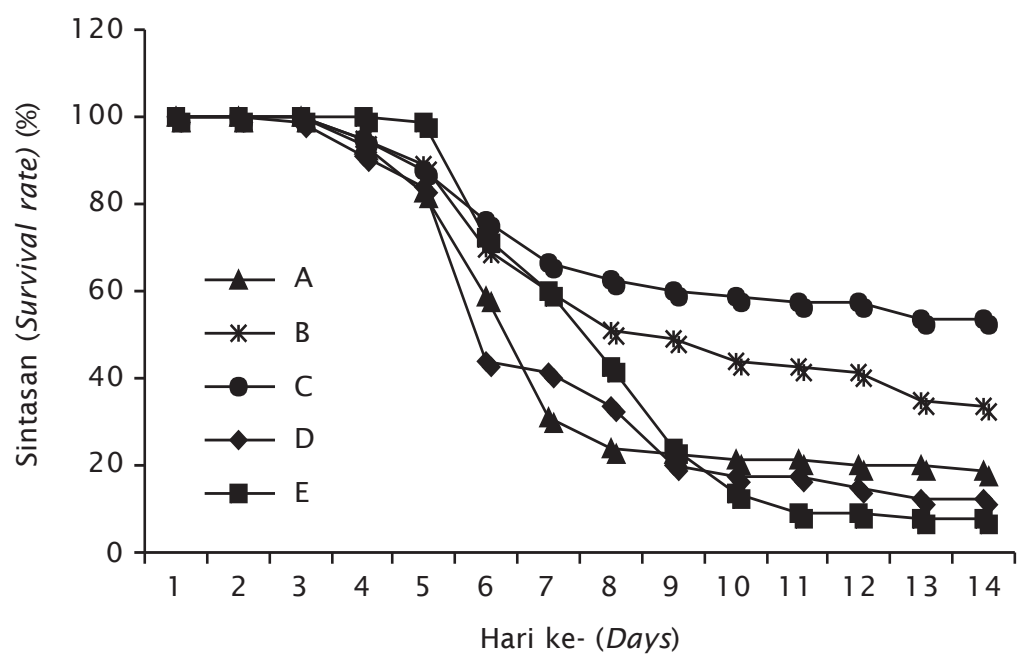

Gambar 13. Status kematian ikan masa uji tantang

Figure 13. Fish mortality on challenge test period 


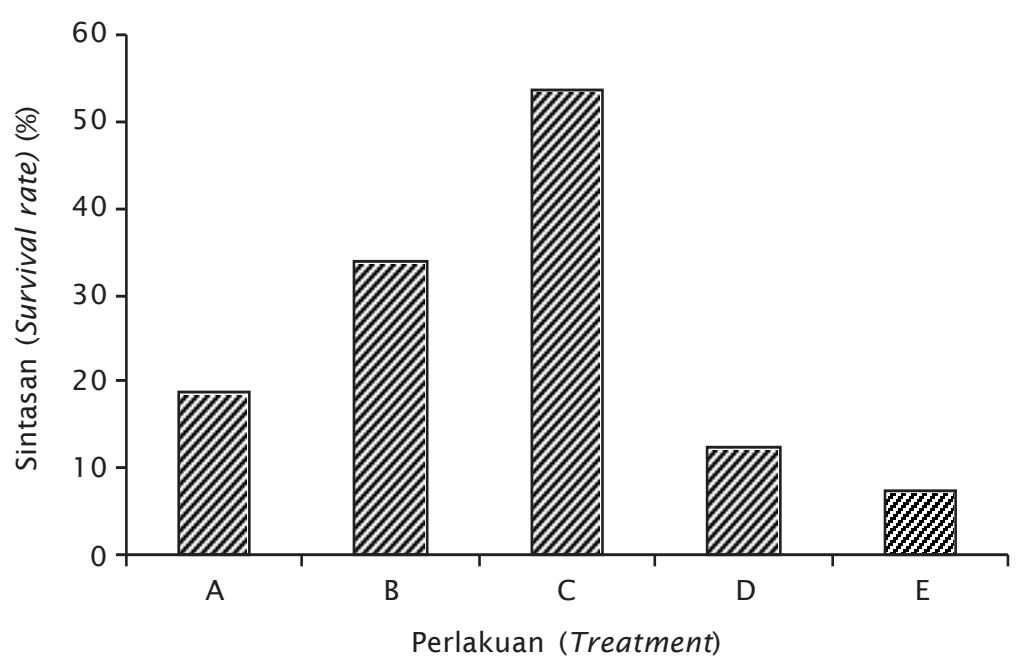

Gambar 14. Rata-rata tingkat sintasan ikan masa uji tantang

Figure 14. The average of fish survival rate on challenge test period

terbentuk sistem kekebalan spesifik KHV yang optimal pada badan ikan mas. Hal itu sesuai dengan pernyataan Hastowo \& Bibiana (1992) bahwa untuk membentuk sistem kekebalan tubuh, ikan perlu masa inkubasi selama dua minggu dan untuk membentuk sistem kekebalan tubuh yang lebih kuat diperlukan waktu masa inkubasi selama 2-3 minggu. Sedangkan rendahnya tingkat sintasan pada perlakuan $\mathrm{D}$ diduga bahwa masa inkubasi empat minggu kurang efektif karena telah melewati masa pembentukan sistem kekebalan optimal.

Dari hasil penelitian ini tingkat sintasan tertinggi didapatkan pada ikan yang dipelihara pada suhu $30^{\circ} \mathrm{C}-34^{\circ} \mathrm{C}$ selama 3 minggu (perlakuan C) yaitu sebesar $53,75 \%$. Ikan yang dipelihara pada suhu $30^{\circ} \mathrm{C}-34^{\circ} \mathrm{C}$ selama 2 minggu telah menghasilkan nilai tingkat sintasan sebesar $33,75 \%$ (perlakuan B), 18,75\% (perlakuan A), 12,5\% (perlakuan D). Nilai paling rendah didapatkan pada ikan kontrol yaitu sebesar 7,5\% (perlakuan E).

\section{Pengamatan Deferensial Leukosit}

Pengamatan diferensial leukosit darah ikan mas dilakukan untuk mengetahui perbandingan respon kekebalan badan ikan mas antara pemeliharaan ikan pada masa aklimatisasi, masa kohabitasi, masa inkubasi virus pada badan ikan mas dan pasca uji tantang. Leukosit (sel darah putih) merupakan sel darah yang berperan dalam sistem kekebalan. Sistem kekebalan berfungsi untuk menjaga homeostasis tubuh dan mempertahankan diri dari invasi patogen. Sel darah putih yang memiliki fungsi utama sebagai sel penting dalam mekanisme kekebalan tubuh spesifik untuk memproduksi antibodi adalah limfosit. Dari hasil uji diferensial leukosit pada perlakuan A, B, C, dan D terdapat peningkatan jumlah limfosit pada masa perlakuan dibandingkan masa aklimatisasi. Pada masa aklimatisasi, ikan dalam kondisi sehat atau bebas virus KHV. Setelah masa kohabitasi jumlah limfosit meningkat. Peningkatan jumlah limfosit itu sebagai respons badan ikan terhadap adanya virus pada badan ikan mas. Kemudian setelah ikan dipelihara pada bak yang bersuhu $30^{\circ} \mathrm{C}-34^{\circ} \mathrm{C}$, limfosit ikan mengalami peningkatan kembali. Hal itu diduga sebagai respon dari kekebalan spesifik yang dibentuk oleh badan ikan mas. Pada suhu tersebut virus tidak mampu bereplikasi sehingga virus yang ada pada badan ikan tidak menjadi patogen yang ganas. Sehingga badan ikan mampu membentuk sistem imun. Namun setelah masa uji tantang jumlah limfosit ikan mas mengalami penurunan (Gambar 15). Hal itu diduga sebagai respon adanya serangan virus yang kedua kali. Karena pada masa uji tantang, suhu tempat ikan hidup disesuaikan dengan suhu lingkungan, yaitu $24^{\circ} \mathrm{C}-27^{\circ} \mathrm{C}$ maka virus mampu bereplikasi dengan cepat. Sesuai dengan pernyataan OATA (2001) bahwa rentang suhu optimal untuk 


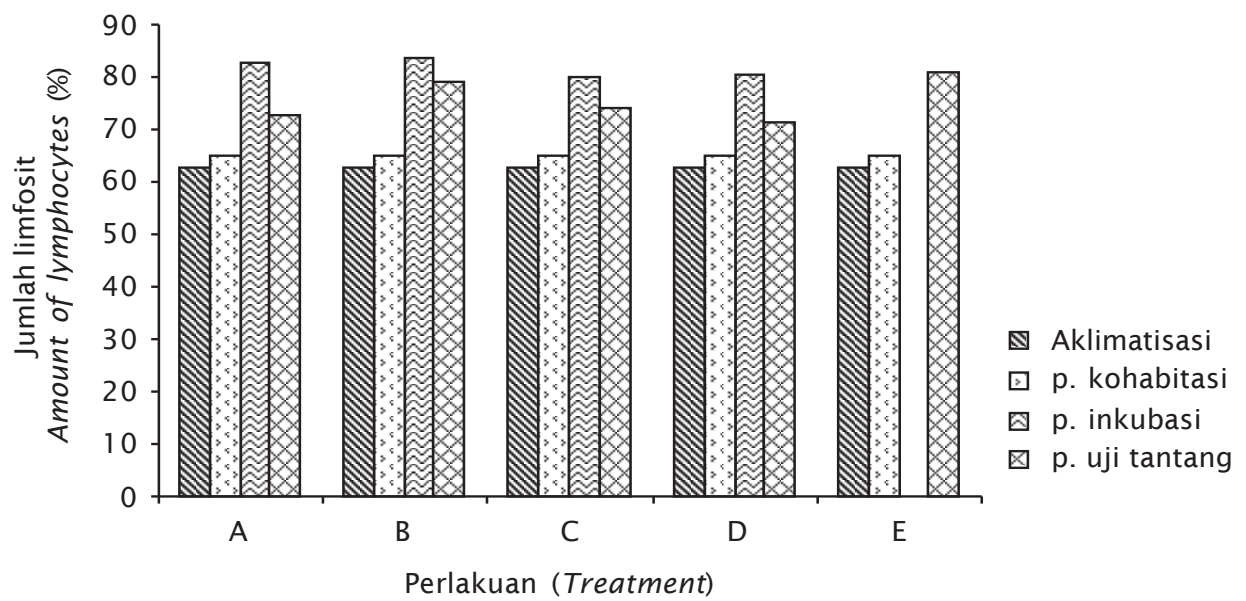

Gambar 15. Jumlah limfosit pada tiap perlakuan

Figure 15. Lymphocytes after treatment

perkembangan virus KHV pada ikan mas berkisar antara $18-27^{\circ} \mathrm{C}$. Sehingga limfosit yang terbentuk dimanfaatkan untuk melawan invasi virus KHV.

Berbeda dengan jumlah limfosit yang mengalami peningkatan pada masa pemeliharaan dalam suhu $30^{\circ} \mathrm{C}-34^{\circ} \mathrm{C}$, neutrofil mengalami penurunan dibandingkan dengan masa kohabitasi (Gambar 16). Adanya penurunan jumlah neutrofil diduga karena ikan nyaman pada tempat tersebut, sehingga ikan terhindar dari serangan bakteri patogen. Sedangkan pada masa uji tantang jumlah neutrofil mengalami peningkatan. Hal itu diduga sebagai respon ikan terhadap serangan bakteri. Pada masa uji tantang ini, selain adanya serangan virus KHV, ikan juga mengalami serangan dari bakteri patogen.

Pada Gambar 17 terlihat adanya peningkatan jumlah monosit perlakuan $B$ dan $C$ pada masa pemeliharaan ikan dalam suhu $30^{\circ} \mathrm{C}-34^{\circ} \mathrm{C}$. Sedangkan pada perlakuan A dan $D$, jumlah monosit sama seperti pada masa aklimatisasi. Pada masa kohabitasi, semua perlakuan mengalami penurunan jumlah monosit.

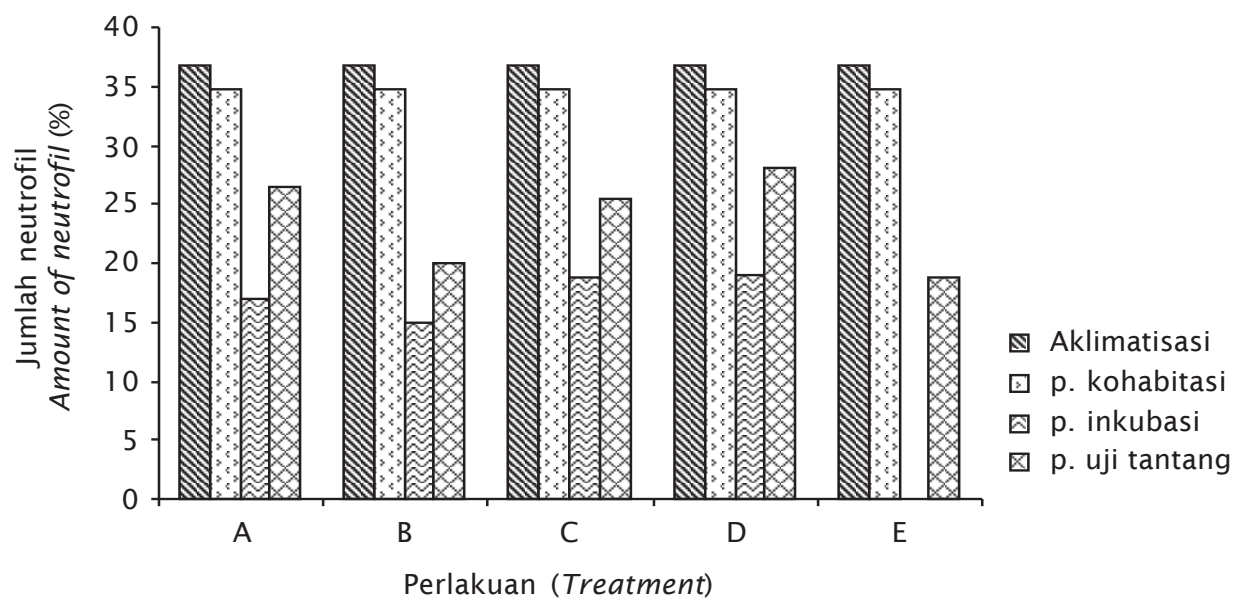

Gambar 16. Jumlah neutrofil pada setiap perlakuan

Figure 16. Neutrofil after treatment 


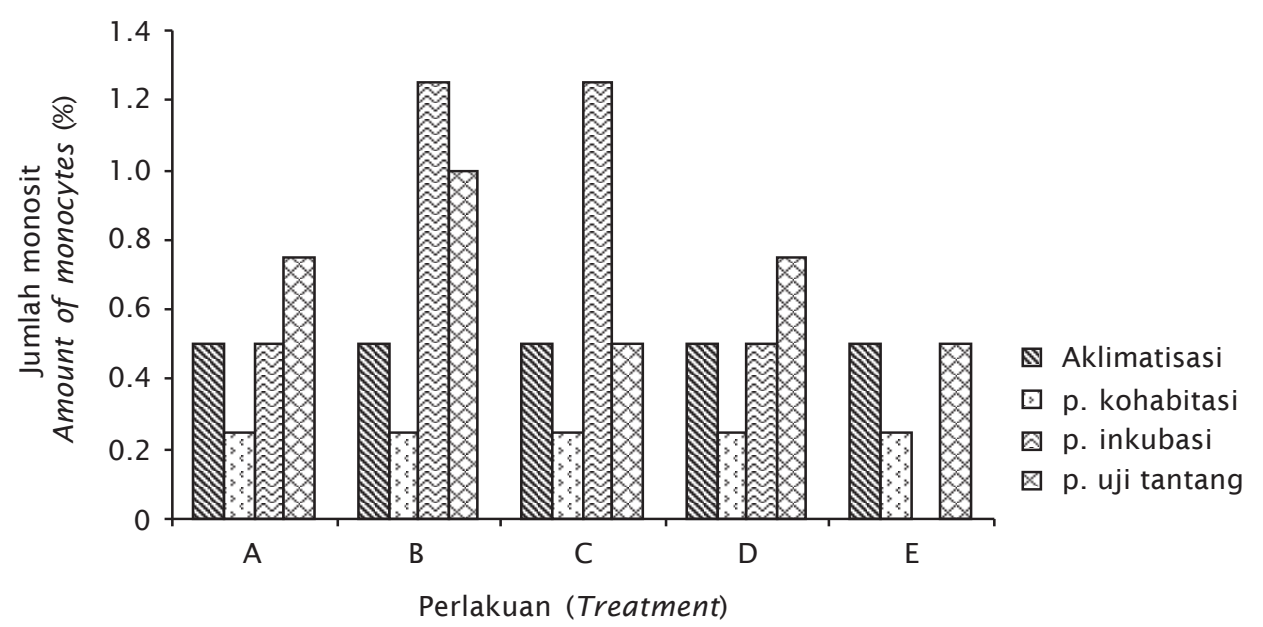

Gambar 17. Jumlah monosit pada tiap perlakuan

Figure 17. Monocytes after treatment

\section{KESIMPULAN DAN SARAN}

Teknik kohabitasi terkontrol merupakan salah satu strategi upaya pencegahan yang prospektif untuk mengendalikan kasus KHV pada ikan mas.

Kohabitasi terkontrol selama 3 hari pada kondisi lingkungan yang sesuai bagi aktivitas KHV (suhu air $24^{\circ} \mathrm{C}-26^{\circ} \mathrm{C}$ ) yang dilanjutkan dengan periode induksi kekebalan spesifik dalam badan ikan mas (suhu air $31^{\circ} \mathrm{C}-34^{\circ} \mathrm{C}$ ) selama 3 minggu memberikan proteksi yang tertinggi terhadap infeksi KHV yang dimanifestasikan dengan tingginya sintasan, yaitu sebesar $53,75 \%$; dibandingkan dengan periode inkubasi selama 1 minggu (18,75\%), selama 2 minggu $(33,75 \%)$, selama 4 minggu $(12,5 \%)$, dan kontrol $(7,5 \%)$.

Penerapan teknik tersebut dapat diaplikasikan pada lingkungan/kawasan budidaya ikan mas yang sudah diketahui bahwa di wilayah tersebut adalah endemis $\mathrm{KHV}$, karena populasi ikan yang telah terinfeksi KHV tetap berpotensi sebagai pembawa (carriers).

Masih perlu dilakukan evaluasi yield gap terhadap efektivitas teknik tersebut di level lapangan yang kondisinya sangat dipengaruhi berbagai faktor (internal \& eksternal), terlebih lagi bahwa teknik kohabitasi sangat berisiko sehingga perlu kontrol strategi yang seksama karena KHV sangat mematikan dan menular pada populasi ikan mas.

\section{UCAPAN TERIMA KASIH}

Riset ini dibiayai oleh DIPA T.A. 2007 Balai Riset Perikanan Budidaya Air Tawar. Penulis mengucapkan terima kasih kepada Saudara Mikdarullah, Edy Farid, Bambang Priadi, dan Ahmad Wahyudi yang telah membantu pelaksanaan kegiatan ini baik di lapangan maupun di laboratorium.

\section{DAFTAR ACUAN}

Anderson, D.P. \& Siwicki, A.K. 1995. Duration of protection against Aeromonas hydrophila. Pubmed, 73: 159-165.

Direktorat Jenderal Perikanan Budidaya. 2002. Kumpulan SNI Bidang Pembudidayaan, 89 hlm.

Gray, W.L., Mullis, L., LaPatra, S.E., Groff, J.M., \& Goodwin, A. 2002. Detection of Koi herpesvirus DNA in tissues of infected fish. Journal of Fish Disease, 25: 171-178.

Hastowo, S. \& Bibiana, W. 1992. Mikrobiologi. Rajawali Pers. Jakarta, hlm. 47-59.

Irianto, A. 2005. Patologi Ikan Teleostei. Gadjah Mada University Press, $256 \mathrm{hlm}$.

Khairuman. 2002. Budidaya Patin Super. Agro Media Pustaka, Jakarta, 64 hlm.

Ornamental Aquatic Trade Association (OATA). 2001. Koi Herpesvirus KHV. OATA, Westbury, Wilts, UK, p. 4-33.

Taukhid, Sunarto, A., Koesharyani, I., Supriyadi, H., \& Gardenia, L. 2004. Strategi pengendalian penyakit koi herpes virus (KHV) pada 
ikan mas dan koi. Makalah dipresentasikan pada Workshop pengendalian penyakit Koi Herpes Virus (KHV) pada budidaya ikan air tawar, Bogor, 28 September 2004, hlm. 1-10.

Taukhid, Sunarto, A., Koesharyani, I., Supriyadi, H., \& Gardenia, L. 2005a. Strategi pengendalian penyakit Koi Herpes Virus (KHV) pada ikan mas dan koi. Serial Bunga Rampai: Strategi Pengelolaan dan Pengendalian Penyakit KHV, suatu upaya pemecahan dalam pembudidayaan ikan air tawar. Pusat Riset Perikanan Budidaya, Badan Riset
Kelautan dan Perikanan, Departemen Kelautan dan Perikanan, hlm. 41-60.

Taukhid, Sumiati, T., \& Koesharyani, I. 2005 . Pengaruh suhu air dan total bahan organik terlarut terhadap patogenisitas Koi Herpes Virus pada ikan mas (Cyprinus carpio). Serial Bunga Rampai: Strategi Pengelolaan dan Pengendalian Penyakit KHV, suatu upaya pemecahan dalam pembudidayaan ikan air tawar. Pusat Riset Perikanan Budidaya, Badan Riset Kelautan dan Perikanan, Departemen Kelautan dan Perikanan, hlm. 83-94. 